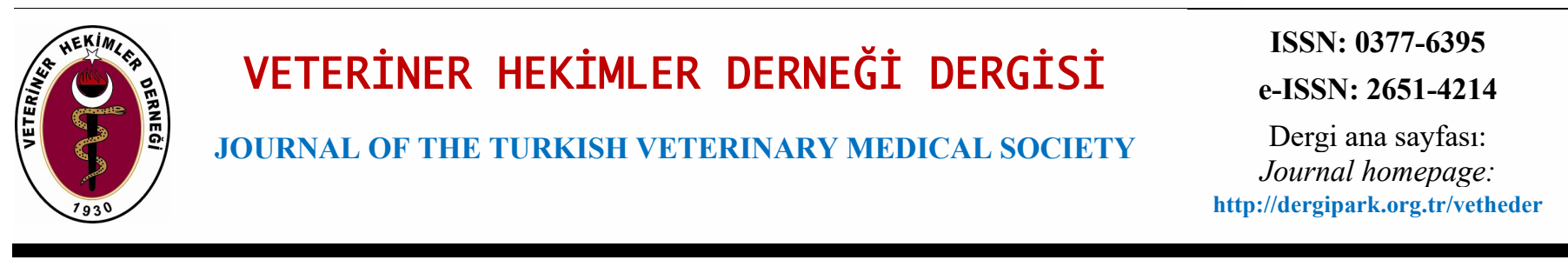

DOI: $10.33188 /$ vetheder. 871288

Olgu Sunumu / Case Report

\title{
A case of ectrodactyly in a 2-years-old mixed breed dog
}

\author{
Birkan KARSLI ${ }^{1, a^{*}}$, Merve BAKICI ${ }^{1, b}$ \\ ${ }^{1}$ University of Kirikkale, Faculty of Veterinary Science, Department of Surgery, Klrlkkale, Turkey \\ ORCID: 0000-0003-4208-3134 ${ }^{a}$;0000-0001-8833-3499 ${ }^{b}$
}

MAKALE BILGISI /
ARTICLE
INFORMATION:
Geliş / Received:
30 Ocak 2021
30 January 2021
Revizyon / Revised:
11 Nisan 2021
11 April 2021
Kabul / Accepted:
20 Mayis 2021
20 May 2021
Anahtar Sözcükler:
Ektrodaktili
Köpek
Pankarpal atrodez
Keywords:
Ectrodactyly
Dog
Pancarpal arthrodesis

\begin{abstract}
:
Ectrodactyly is a rare anomaly seen in the appendicular skeleton and characterized by a cleft or split between bone and soft tissue in the distal regions of the extremities. Ectrodactyly may be associated with the absence and hypoplasia of several carpal-metacarpal bones, phalanx duplication, or metacarpal synostosis. In this case report, a 2-years-old mixed breed male dog was presented withhold up the left forelimb and inspectional abnormality with a cleft. In the radiographic images, it was observed that the fourth phalanx and the fourth distal carpal bone were absent in the related extremity, the cleft extended up to the carpal joint and there was an incongruity between the radius and ulna. The cleft between the metacarpal bones was stabilized using 2 lag screws and corticocancellous bone graft. The incongruity between the carpal joints was eliminated by pancarpal arthrodesis and ulna ostectomy was performed for the incongruity between radius and ulna. It has been observed that postoperative physical therapy exercises with correlated methods have positive long-term results in the related extremity.
\end{abstract}

\section{2 yaşlı melez ırk bir köpekte ektrodaktili olgusu}

ÖZET:

Ektrodaktili, apendiküler iskelette görülen nadir bir anomali olup, ektremitelerin distal bölgelerinde kemik ve yumuşak doku arasında şekillenen yarık ya da bölünme ile karakterizedir. Ektrodaktili birkaç karpal-metacarpal kemiğin yokluğu/hipoplazisi, phalanks duplikasyonu ya da metacarpal sinostos ile ilişkili olabilir. Bu olgu sunumunda 2 yaşında, melez ırk, erkek bir köpek, sol ön ekstremitesini yukarıda tutma ve dış bakıda gözlenebilen bir yarık şikayeti ile getirildi. Alınan radyografik görüntülerde ilgili ekstremitede dördüncü phalanx’ın ve dördüncü distal carpal kemiğin olmadığı, yarığın carpal ekleme kadar uzandığı ve radius ile ulna arasında uyumsuzluk olduğu görüldü. Metacarpal kemikler arasındaki yarık 2 adet lag vidası ve kortikokansellöz kemik grefti kullanılarak stabilize edildi. Carpal eklemler arasındaki uyumsuzluk pancarpal artrodez yöntemi ile giderildi ve radius ile ulna arasındaki uyumsuzluk için ulna ostektomisi uygulandı. Uygulanan korrektif yöntemler ile operasyon sonrası uygulanan fizik tedavi egzersizlerinin, ilgili ekstremitedeki uzun dönem sonuçlarının olumlu olduğu gözlenmiştir.

How to cite this article: Karslı B, Bakıcı M: A case of ectrodactyly in a 2-years-old mixed breed dog. Veteriner Hekimler Dernegi Dergisi, 92(2): 181187, 2021, DOI: $10.33188 /$ vetheder.871288 


\section{Introduction}

Ectrodactyly is rare dysostosis of the appendicular skeleton. It is a congenital abnormality that occurs due to the deficiency of one or more structural components, which is shaped by a developmental disorder during embryogenesis (9). It is known with various names including splint hand deformity-hipodactyly-oligodactyly or lobster claw syndrome (4).

It is characterized by a cleft or division that is shaped in varying degrees between bone and soft tissue in the distal regions of the extremities $(2,21)$. Ectrodactyly can be associated with absence / hypoplasia of the carpalmetacarpal bone, phalanx duplication, or metacarpal synostosis $(4,12)$. The cleft can extend from phalanges to metacarpal bones, carpal joints, and even antebrachium $(2,15)$. Ulna can be shorter in the affected extremity and luxation in the elbow joint $(8,14)$.

The disease is generally unilateral. Up to now, two bilateral cases have been presented $(3,4)$. The disorder has been seen in many mammal species such as dogs (11), cats (20), foals (1), sheep (17), calves (18), primates (5), tigers (16), and amphibians (10). In humans, it is frequently seen with tibial aplasia, craniofacial defects (cleft palate), and urogenital anomalies (13). In this study, it was aimed to increase the quality of life of the dog by performing the surgical management of ectrodactyly, which is a rare case.

\section{Case Story}

A 2-years-old male mixed breed dog was presented with non-weight bearing left forelimb and cleft on the paw to Kırıkkale University Veterinary Faculty Research and Application Hospital. During the physical examination, it was observed that there was a cleft between the third and fifth phalanx, including bone and skin, extending to the carpal joint region (Figure 1).
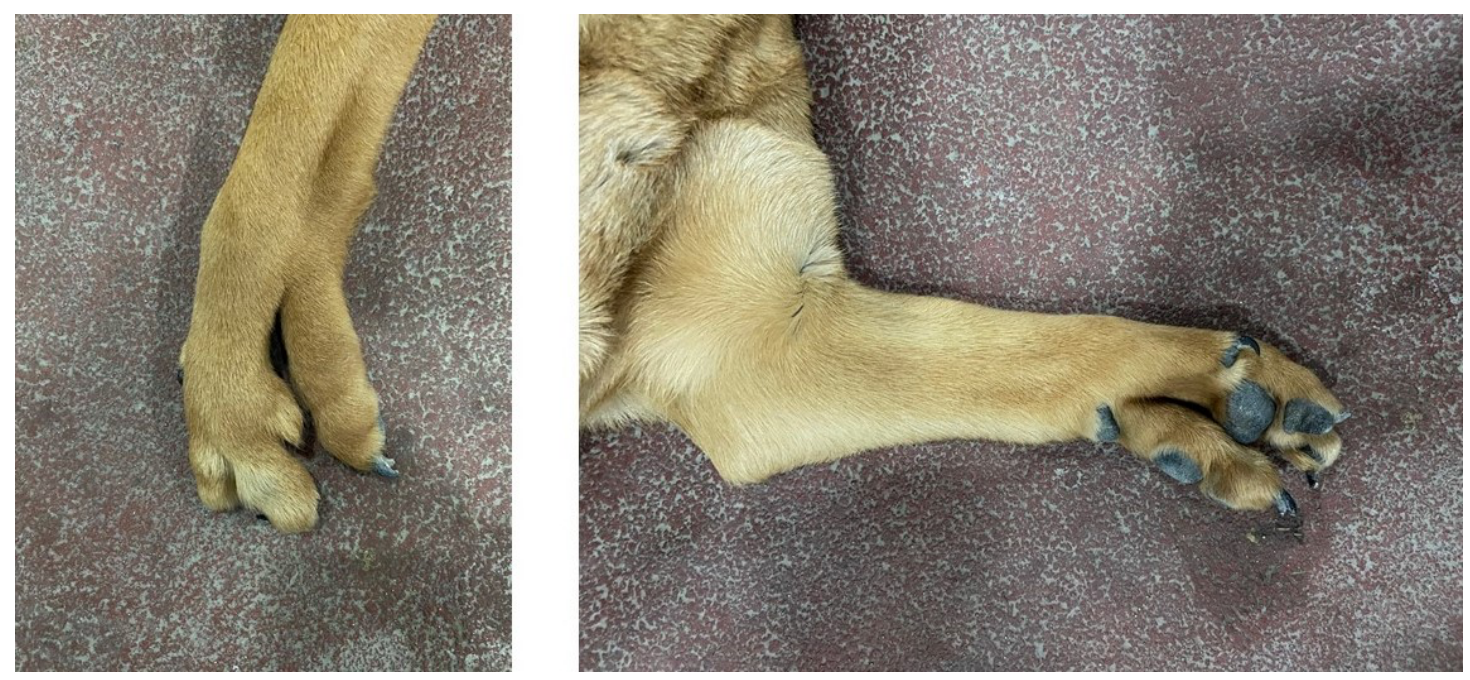

Figure 1: Cleft from the distal phalanx to the carpal area in the left forelimb.

Şekil 1: Sol ön extremitede distal phalanxtan carpal bölgeye kadar uzanan yarlk.

It was seen that the fourth finger and the fourth distal carpal bone were absent in the dorsopalmar and laterolateral radiographs, and there was a lateral deviation in the third and fifth distal phalanges. Although the ulna of the affected limb was shortened compared to the contralateral limb, elbow dislocation did not occur. (Figure 2a and $2 b)$. The identification of the skeleton of the manus is given in figure 3 . 


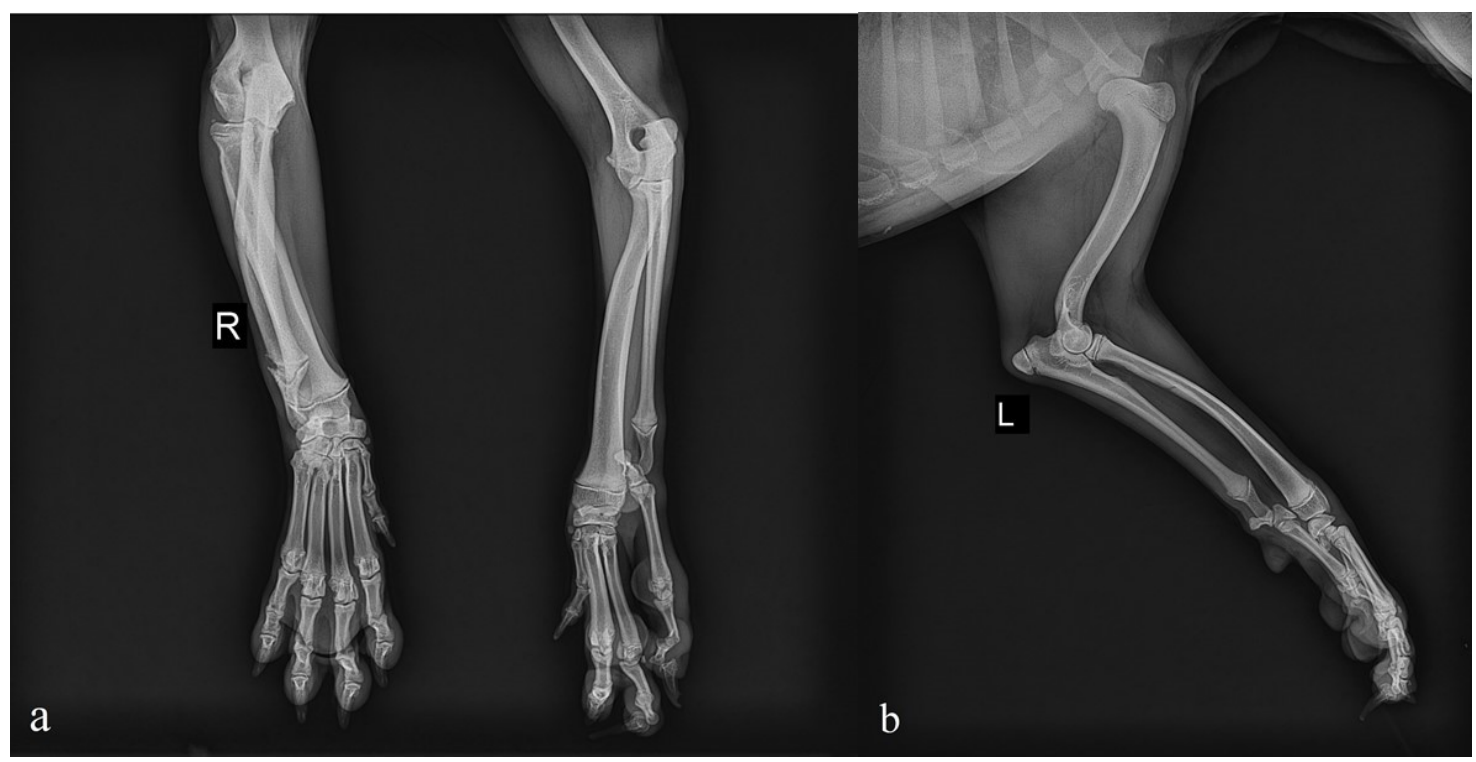

Figure 2: Dorsopalmar (a) and M / L (b) radiographic images of the affected limb.

Şekil 2: Etkilenen extremitenin dorsopalmar (a) ve M / L (b) radyografik görüntüsü.

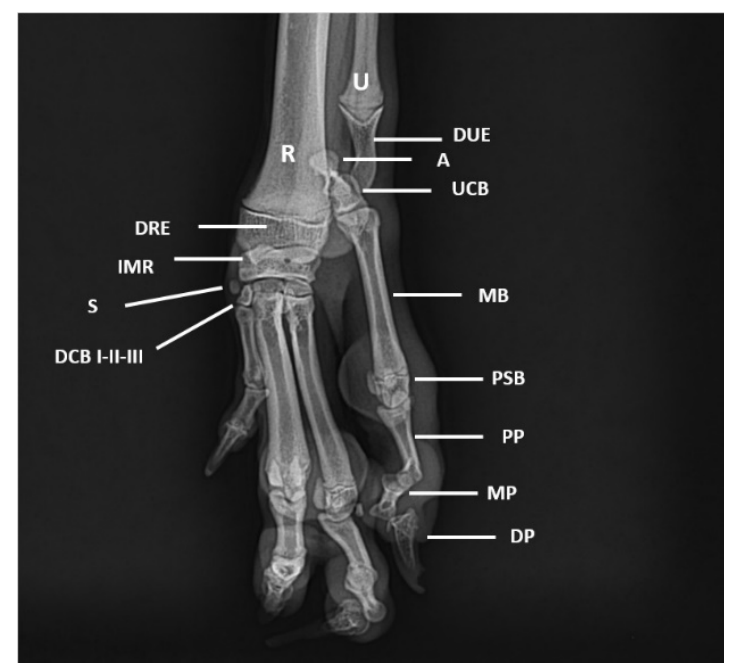

Figure 3: Dorsopalmar radiography of the affected limb. R-radius; U-ulna; DUE- distal ulnar epiphysis; DRE- distal radial epiphysis; A-accessory carpal bone; UCB-ulnar carpal bone; IMR- intermediolateral bone; SSesamoid bone; DCB I-II-III-distal carpal bone I-II-III; MB-metacarpal bone; PSB-proximal sesamoid bones; PPproximal phalanx; MP-middle phalanx; DP-distal phalanx.

Şekil 3: Etkilenen extremitenin dorsopalmar radyografisi. R-radius; U-ulna; DUE-distal ulnar epifiz; DREdistal radial epifiz; A-os carpi accessorium; UCB-os carpi ulnare; IMR-os carpi intermedium; S-Os sesamoideum; DCB I-II-III-os carpale I-II-III; MB-os metacarpale; PSB-os sesamoideum proximale; PP-phalanx proximalis; MPphalanx media; DP-phalanx distalis.

Induction of anesthesia was performed with $1 \mathrm{mg} / \mathrm{kg}$ i.m. xylazine (Xylazine Bio 2\%; Bioveta, Czech Republic) and $6 \mathrm{mg} / \mathrm{kg}$ i.m. ketamine HCI (Ketasol 10\%; Richterpharma, Austria). Anesthesia was maintained with isoflurane (Adeka, Turkey) and a continuous rate infusion of lactated Ringer's solution $10 \mathrm{ml} / \mathrm{kg} / \mathrm{h}$ i.v. (Ringesol, Vilsan, Turkey) was administered $0.2 \mathrm{mg} / \mathrm{kg}$ butorphanol i.v (Butomidor; Richterpharma, Austria) was administered perioperatively. In the postoperative period, $0.2 \mathrm{mg} / \mathrm{kg}$ meloxicam s.c. (Maxicam; Sanovel, Turkey) was used for 
analgesia (4 days). For the antimicrobial treatment, $25 \mathrm{mg} / \mathrm{kg}$ p8h cefazoline iv (Eqizolin; Tüm team ilaç A.Ş, Turkey) was administered for five days.

Bone and soft tissue reconstruction technique with ulna ostectomy and pancarpal arthrodesis was applied in the surgical procedure, proximal ulnar ostectomy, with the removal of $1 \mathrm{~cm}$ of bone was performed. A corticocancellous autogenous bone graft taken from the proximal humerus was placed between the third and fifth metacarpal bones and fixed with two $2 \mathrm{~mm}$ lag screws bicortically. Periostectomy of the antebrachiocarpal-intercarpal-carpometacarpal joint surfaces and pancarpal arthrodesis of the joint was performed by placing three screws proximally and distally with a multiaxial locking plate (Figure 4).
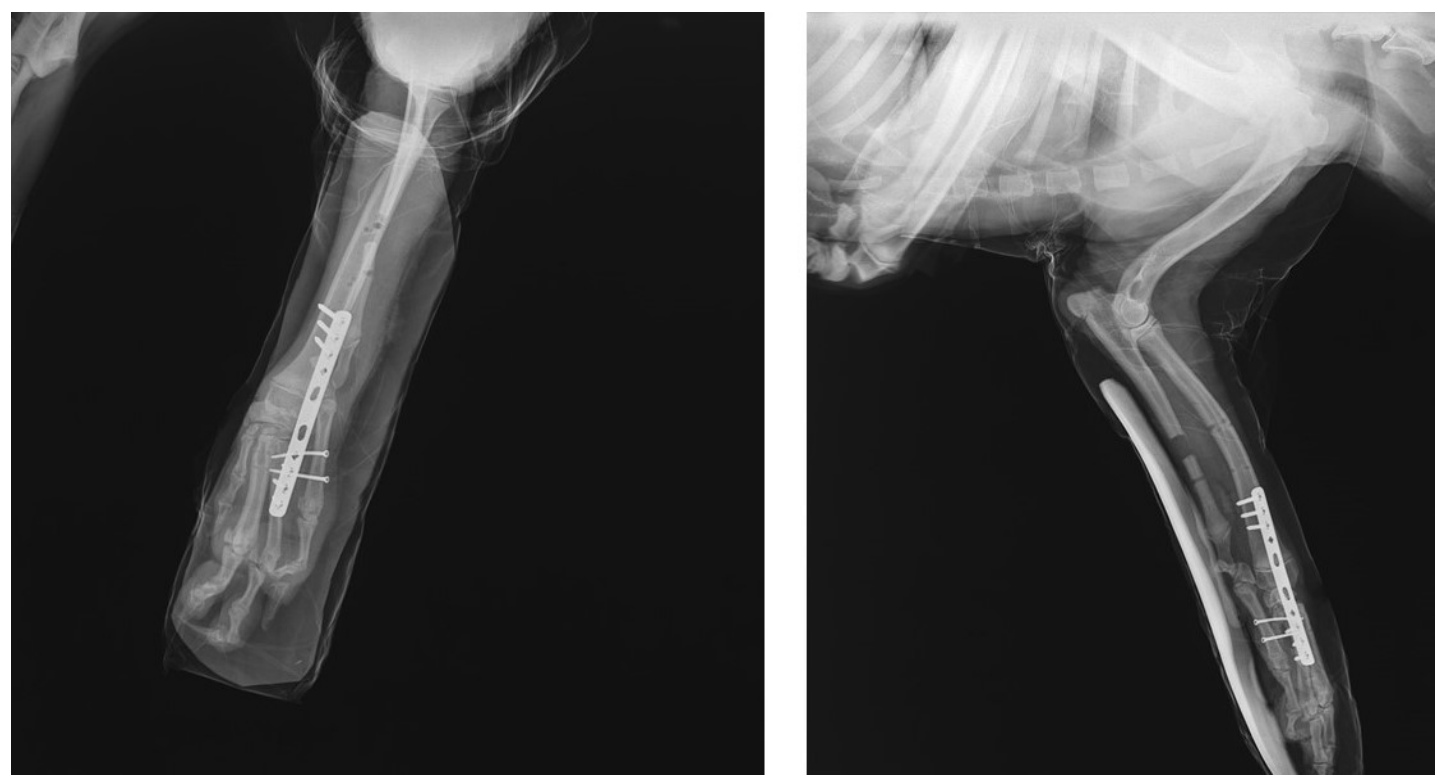

Figure 4: $\mathrm{A} / \mathrm{P}$ and $\mathrm{M}$ / L view of the extremity on postoperative radiographic images.

Şekil 4: Extremitenin postoperatif dönemde alınan A / P ve M / L radyografik görüntüsü.

The limb was put on a gutter splint for two weeks and the dog's movements were restricted. At the end of the second week, passive movements (extension and flexion) and controlled walks were started. Controlled walks were applied with $0.75 \mathrm{~kg}$ of leg weights attached to the extremity. The patient was discharged after applying physical therapy exercises for 3 weeks. At that time, it was observed that the animal used its extremity from time to time while walking (Figure 5a). It was observed that the bone healed on the radiographs taken in the postoperative 3rd month (Figure 6). It was seen that the animal was using its extremity comfortably in the examination performed in the postoperative 6th month (Figure $5 \mathrm{~b}$ ). 

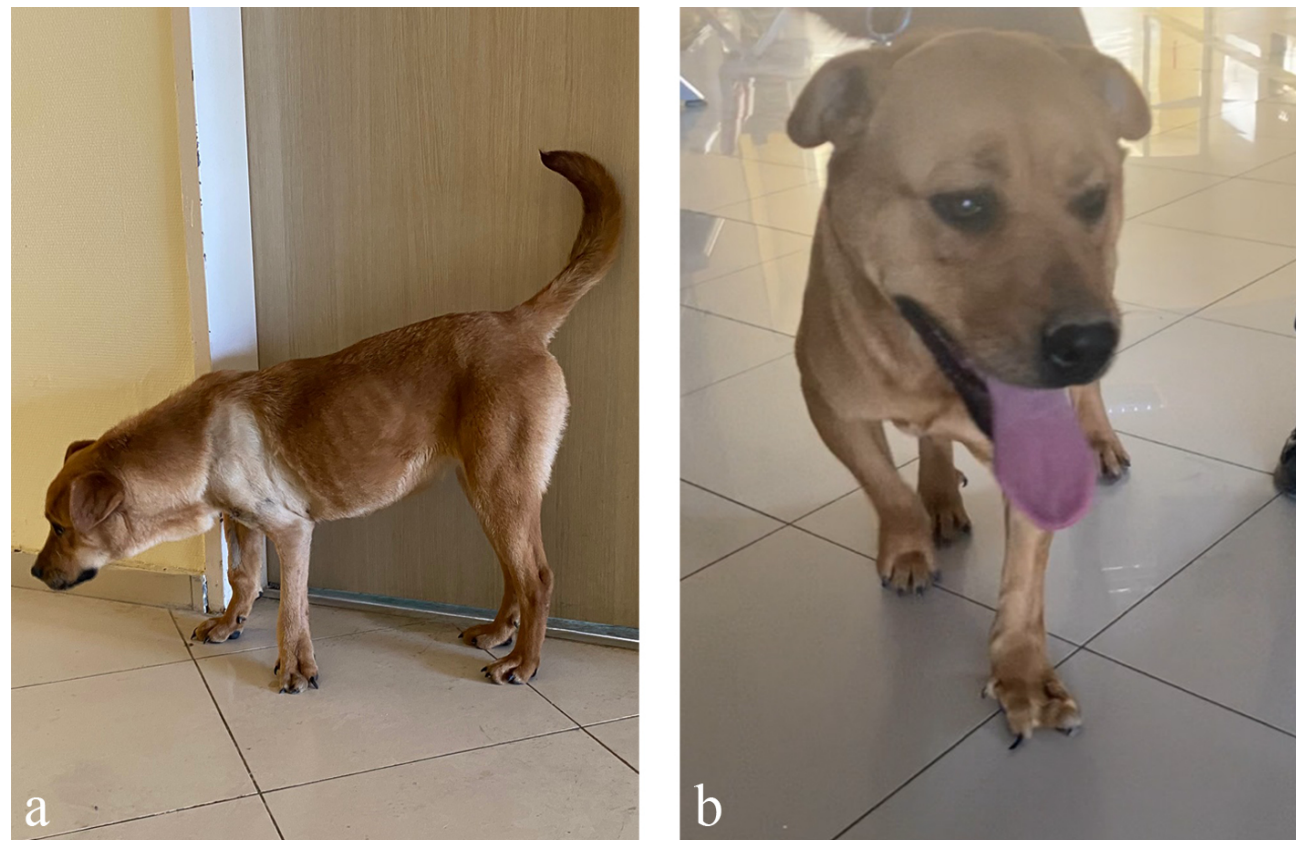

Figure 5: Clinical photographs of the dog postoperative third week (a) and sixth month (b).

Şekil 5: Köpeğin postoperatif üçüncü hafta (a) ve altıncı aydaki (b) klinik görüntüsü.
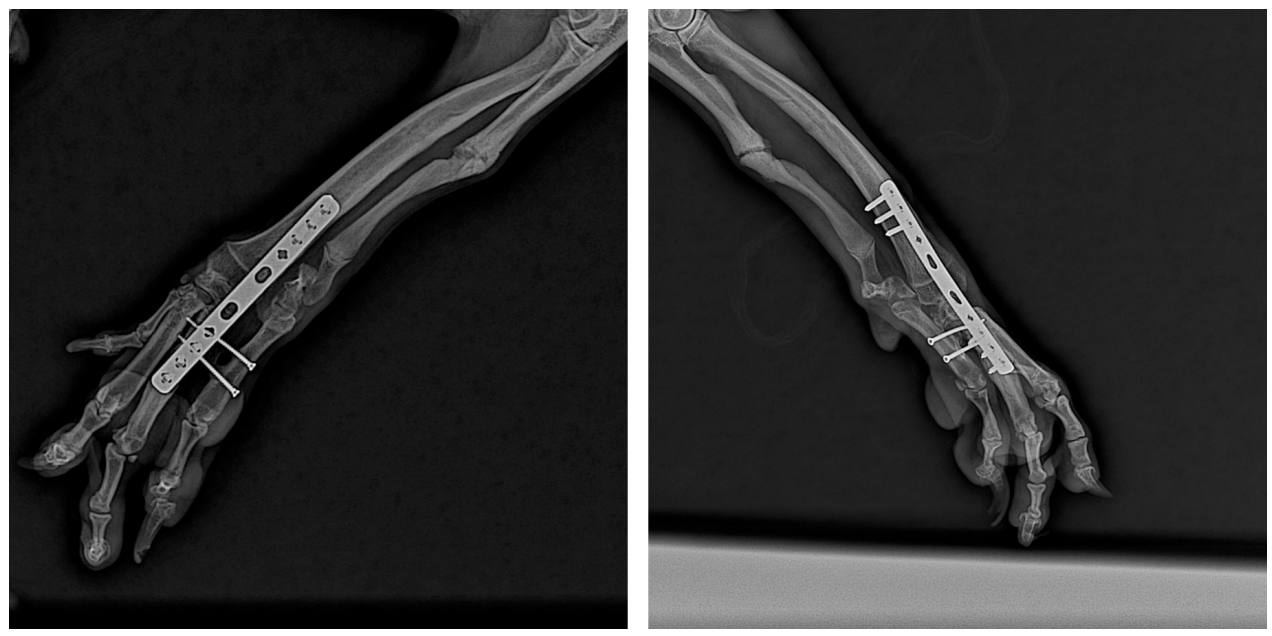

Figure 6: $\mathrm{A} / \mathrm{P}$ and $\mathrm{M} / \mathrm{L}$ radiography taken at the third month postoperative control.

Şekil 6: Postoperatif üçüncü ay kontrolünde alınan A / P ve M / L radyografik görüntü.

\section{Discussion and Conclusion}

Although cases of ectrodactyly in humans are generally seen with abnormalities such as cleft palate associated with ectodermal dysplasia, cleft palate was described in only one case in animals $(8,19)$. Ectrodactyly is usually related to abnormalities in the medial and central ray. The effect of the fourth phalanx, in this case, is similar to previous studies $(2,4)$. Soft and bone tissue separation most often involved the metacarpus. Although concomitants ipsilateral elbow luxation might occur in animals with ectrodactyly due to the difference in length between ulna and radius in the ipsilateral extremity $(4,7)$, this alteration was not observed in the presented case. Carring et al. (4) reported that 
abnormalities such as bone hypoplasia, soft tissue contraction, and bone fusion (syndactyly) can be seen in dogs with ectrodactyly. In this study, there is a shortening and hypoplasia of ulna. In previous studies, dogs treated for ectrodactyly were mostly between the ages of 2 and 3 months old $(2,6-8,14,15,22)$. However, in this study, the age at which brought to the hospital for treatment was two years old. Since the rate of bone healing in young and adult animals is not the same, a comparison regarding healing could not be made. On the other hand, a case of ectrodactyly was described in a 3-years-old dog and was not surgical treatment due to the presence of concurrent spinal deformation (3). In this study, reconstructive surgery techniques were used.

No treatment is required when the extremity function is not affected in cases. Reconstruction techniques should be applied with severe disorders. The primary purpose of reconstruction techniques is to stop the progression of the deformity and to increase the animal's quality of life $(2,6-8)$. The most common technique used in ectrodactyly is carpal arthrodesis or pancarpal arthrodesis (2). The aim of this study is not to prevent the progression of the deformity, but to correct the abnormality and to facilitate the animal to use its extremity. Carpal arthrodesis has been used successfully in various animals (2). In this study, pancarpal arthrodesis was applied to eliminate instability in the carpal region. Leg weights are effective for building muscle and can increase proprioceptive input (23). We also applied exercises with leg weights to strengthen the muscles of the region that became atrophic due to not using the extremity and to encourage the animal to use its extremity.

In conclusion, it was thought that pancarpal arthrodesis, physical therapy, and ulna ostectomy can be used as alternative methods in the treatment of ectrodactyly cases seen in different animal species. It was seen that the affected extremities are effective in increasing the living standard of the animal by using these methods together.

\section{Conflict of Interest}

The authors declared that there is no conflict of interest.

\section{Funding}

This study was not supported or not studied granting by any foundation.

\section{Authors' Contributions}

Idea / concept: Birkan Karsl1, Merve Bakıc1

Experiment design: Merve Bakıcı

Supervision / Consultancy: Birkan Karsl1

Data collecting: Sedat Sevin, Birkan Karsl1, Merve Bakıcı

Data analysis and interpretation: Birkan Karsl1, Merve Bakıcı

Literature search: Merve Bakıc1

Writing the article: Merve Bakıcı

Critical review: Birkan Karslı, Merve Bakıcı

\section{Ethical Statement}

An ethical statement was received from the authors that the data, information and documents presented in this article were obtained within the framework of academic and ethical rules and that all information, documents, evaluations and results were presented in accordance with scientific ethics and moral rules.

\section{References}

1. Azizi S, Kuhi M, Kheirandish R, Asadabadi A, Abdoli V (2017): Two foals with ectrodactyly in hindlimb: first report. Comp Clin Pathol, 26, 723-725.

2. Barrand KR (2004): Ectrodactyly in a westhighland white terrier. J Small Anim Pract, 45, 315-318.

3. Carvallo FR, Dominguez AS, Morales PC (2010): Bilateral ectrodactyly and spinal deformation in a mixedbreed dog. Can Vet J, 51, 47-49. 
4. Carrig, CB, Wortman, JA, Morris EL, Blevins WE, Root CR, Hanlon GF, Suter PF (1981): Ectrodactyly (split-hand deformity) in the dog. Veterinary Radiology, 22, 123-144.

5. Cooper JE, Purton P, Poswillo DE (1990): A lobster claw abnormality in the common marmoset (Callithrix jacchus). Laboratory Animals, 24, 151-155.

6. Ferreira MP, Alievi MM, Beck CAC, Voll J, Muccillo MS, Gomes C (2007): Ectrodactyly in dog: case report. Arq Bras Med Vet Zootec, 59, 910-913.

7. Harasen G (2010): Surgical management of ectrodactyly in a Siberian husky. Can Vet J, 51, 421-42.

8. Innes JF, McKee W, Mitchell RAS, Lascelles BDX, Johnson KA (2001): Surgical reconstruction of ectrodactyly deformity in four dogs. Vet Comp Orthop Traumatol, 14, 201-209.

9. Jubb KVF, Kennedy CP, Palmer N (2007): Pathology of domestic animal, 5th edn. In: Maxie G (ed), Academic Press, New York.

10. Meteyer CU, Loeffler IK, Fallon JF, Converse KA, Green E, Helgen JC, Kersten S, Levey R, Eaton L, Burkhart JG (2000): Hindlimp malformation in free living nothern leopard frogs (Rana pipiens) from Maine, Minessota and Vermont suggest multiple etiologies. Teratology, 62, 151-171.

11. Montgomery M, Tomlinson J (1985): Two cases of ectrodactyly and congenital elbow luxations in the dog. J Am Anim Hosp Assoc, 21, 781-785.

12. Oliveira D, Artoni SMB (2002): Ectrodactilia em cão (Canis domestica). Ciência Rural, Santa Maria, 32, 1063-1065.

13. Pinette M, Garcia L, Wax JR, Cartin A, Blackstone J (2006): Familial ectrodactyly. J Ultrasound Med. 25, 1465.

14. Pisoni L, Del Magno S, Cinti F, Dalpozzo B (2014): Surgical induction of metacarpal synostosis for treatment of ectrodactyly in a dog. Vet Comp Orthop Traumatol, 27, 166-171.

15. Pratschke K (1996): A case of ectrodactyly in a dog. Irish Vet J, 49, 412-413.

16. Rahal SC, Volpi RS, Teixeira CR, Machado VMV, Soares GDP, Neto CR, Linn K (2012): Congenital deformity of the paw in a captive tiger: Case report. BMC Vet Res, 29, 8- 98.

17. Ramadan RO (1993): Hemimelia and ectrodactyly in a Najdi sheep. Agri-Practice, 14, 30-32.

18. Rao AVN, Murthy TS (1981): Ectrodactyly in a buffalo calf. Ind Vet J, 58, 834.

19. Roelfsema N, Cobben J (1996): The EEC syndrome: A literature study. Clinical Dysmorphology, 5, 115127.

20. Searle AG (1953): Hereditary "splint-hand" in the domestic cat. Ann Eugen, 17, 279-283.

21. Towle HA, Breur GJ (2012): Miscellaneous Orthopedic Condition. 1112-1126. In: Tobias KM, Johnston SA (ed). Veterinary Surgery: Small Animal. St Louis, Missouri: Elsevier, Saunders.

22. Yardımcı C (2017) Surgical management of ectrodactyly in a Turkish Kangal dog. Ankara Üniv Vet Fak Derg, 64, 229-233.

23. Zink C, Dyke JBV (2018): Canine sport medicine and rehabilitation. 2nd edn. Willey Blackwell. 